\title{
In Vitro Dissolution Pattern of Metronidazole Film Coated Tablet in Presence of Fruit Juice
}

\author{
Faisal Asif ${ }^{1}$, Tania Sultana ${ }^{1}$, Md. Didaruzzaman Sohel ${ }^{1, *}$, Md. Helal Uddin Sumon ${ }^{2}$, Md. Hassan Kawsar ${ }^{1}$, Md. \\ Ashraful Islam ${ }^{1}$ \\ ${ }^{1}$ Department of Pharmacy, State University of Bangladesh, Dhaka, Bangladesh \\ ${ }^{2}$ Department of Pharmacy, University of Development Alternative, Dhaka, Bangladesh \\ *Corresponding author: sohelphr15@gmail.com
}

Received December 13, 2013; Revised January 14, 2014; Accepted February 20, 2014

\begin{abstract}
This study concentrates on dissolution of drug in presence of fruit juice specifically mango juice. This work aspires current research to study the dissolution approach pattern of commercial formulation of metronidazole in Bangladesh commercially available eight brands of metronidazole film coated tablets were studied in gastric medium (pH 1.2). All brands got reasonably higher dissolution release mainly M02 (84.79\%), M05 (75.86\%), M06 (72.53\%) and M07 (86.48\%) were released relatively faster than other sample in 15 to 50 minutes. Therefore, Mango juice assists to enhance the therapeutic response of metronidazole on set of quick response.
\end{abstract}

Keywords: dissolution study, gastric medium, mango juice, metronidazole release

Cite This Article: Faisal Asif, Tania Sultana, Md. Didaruzzaman Sohel, Md. Helal Uddin Sumon, Md. Hassan Kawsar, and Md. Ashraful Islam, "In Vitro Dissolution Pattern of Metronidazole Film Coated Tablet in Presence of Fruit Juice." American Journal of Pharmacological Sciences, vol. 2, no. 2 (2014): 32-36. doi: 10.12691/ajps-2-2-1.

\section{Introduction}

Metronidazole (5-nitroimidazole) has a selective activity against anaerobic microorganisms, including bacteria and protozoa. It is usually bactericidal at low concentrations, and its spectrum of activity encompasses almost all anaerobic bacteria and some capnophilic organisms [1]. Metronidazole is the drug of choice for the treatment of various parasitic infections, pseudomembranous colitis, anaerobic infections, acne rosacea, Helicobacter pylori and Crohn's disease and has been used in clinical practice for many years [2]. The chemical structure of metronidazole has shown in Figure 1 adapted from reference [3].

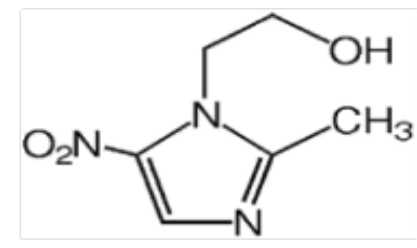

Figure 1. The chemical structure of 2-(2-methyl-5-Nitro-1H-imidazol-1yl) ethanol also known as Metronidazole

Metronidazole is rapidly absorbed from the small intestine on through oral administration including distribution all tissues and fluids. In liver metabolism through oxidation and conjugation process with glucuronic acid. It eliminates with urine concluding 7-8 hours of half-life period. Normally available in 400-800 mg film coated tablet and show interaction with alcohol medication [4]. Many studies prove that a huge portion of drugs is interacted different foodstuffs, drugs, beverages, juices and environmental chemical reagents [5]. Many drugs interact with fruit juice such as dihydropyridines, terfenadine, saquinavir, cyclosporine, midazolam, triazolam and verapamil, ergotamine, nimodipine, fluvoxamine, codeine, tramadol, oxycodone, hydrocodone, carbamazepine, imatinib, loperamide, losartan, dextromethorphan, repaglinide, buspirone, amiodarone, dronedarone, quinidine, disopyramide, propafenone, carvedilol, cisapride, felodipine, nicardipine, difedipine, nisoldipine, nitrendipine, sildenafil, tadalafil, vardenafil, dihydrocodeine, omeprazole, zolpidem, methadone, trazodone, praziquantel, albendazole, lovastatin, astemizole and mebendazole etc. [6-15]. In vitro dissolution acted as a key function in liberating the drug from the tablet matrix and marking for consequent gastrointestinal assimilation. Actually in vitro dissolution of the drug from the tablet matrix relies on many factors, which includes physiochemical properties, nature of formulation and process manufacturing of drugs [16]. Hence in vitro dissolution study has augmented a very important parameter for assuring product quality as well as for distinguishing formulations of same therapeutic agent [17]. In vitro dissolution study is a crucial artifice for the evaluation of formulation also understanding the potential risks affiliated with specific gastrointestinal environment, dose dumping, and food effects on bioavailability and interaction with other drugs [18]. In Bangladesh, there are many companies producing and marketing metronidazole film coated tablets. Beside the national brand, some international brands are also present in the market. This study deals with the determination of in vitro dissolution 
release and in vitro bioavailability characteristic of most commonly available metronidazole film coated tablet matrix considering with mango juice during administration.

\section{Materials and Methods}

Reference standard of Metronidazole supplied from Techno Drugs Limited. All reagents were analytical grade using for dissolution studies such as hydrochloric acid (Merck, Germany); potassium chloride (Merck, Germany).

\subsection{Instruments}

A Double beam Shimadzu UV-visible spectrometer (UV mini-1700, Shimadzu Corporation, Kyoto, Japan with $1 \mathrm{~cm}$ quartz cells). HANNA HI $2211 \mathrm{pH}$ meter (Romania), automated eight-basket tablet dissolution tester UDA-80 USP Standard (Veego, India).

\subsection{Collection of Samples}

Eight commonly available marketed brands (manufacturing date not exceed more than four months ago from the purchasing time) were collected. The samples were properly checked for their manufacturing batch number, license number, manufacturing date and expiring dates before collecting. They were randomly coded such as M01, M02, M03, M04, M05, M06, M07 and M08 etc. The labeled active ingredients contents of metronidazole were $400 \mathrm{mg}$ and packaged in strip or blister packing. Those were stored $25 \pm 2{ }^{\circ} \mathrm{C}$ for four weeks before the dissolution study for the consequence of organoleptic changes.

\subsection{Preparation of Standard Solutions}

$0.1 \mathrm{gm}$ of standard metronidazole including $40 \mathrm{ml}$ of $0.1 \mathrm{HCl}$ solutions was transferred to the volumetric flask and added up to $100 \mathrm{ml}$.

\subsection{In vitro Dissolution Study}

In vitro dissolution was performed by using US Pharmacopoeia dissolution test type II apparatus at $37 \pm 0.5^{\circ} \mathrm{C}$ with a degree of agitation $50 \mathrm{rpm} /$ minutes and $900 \mathrm{ml}$ of dissolution medium per vessel was used. The dissolution experiment was conducted in two phases, first phase implied the dissolution of $400 \mathrm{mg}$ metronidazole using buffer dissolute on medium. Another phase contained $700 \mathrm{ml}$ of buffer and $200 \mathrm{ml}$ of mango juice including gastric medium (pH 1.2) was required [19].

\subsubsection{Preparation of Gastric Medium}

Preparation of simulated gastric medium $(0.1 \mathrm{~N} \mathrm{HCl}$; $\mathrm{pH} 1.2$ ) for $0.1 \mathrm{~N} \mathrm{HCl}, 11.4 \mathrm{ml}$ of Hydrochloric acid (32\% w/v) was diluted with sufficient water to produce $1000 \mathrm{ml}$ [20]. Eight tablets from each formulation were weighed and placed in the baskets with $900 \mathrm{ml}$ of $0.1 \mathrm{~N} \mathrm{HCl}$ was placed in each vessel and the apparatus was assembled. The operation in the gastric medium was carried out for 60 minutes. Every 5-minute interval, $5 \mathrm{ml}$ of sample solution was withdrawn and filtered. The released drug was assayed by using UV spectrophotometer at $278 \mathrm{~nm}$ [21].

\section{Result and Discussion}

The purpose of the study a gradual concentration of solution 5, 10, 15, $20 \mathrm{mg} / \mathrm{ml}$ was constructed for plotting standard curve at $278 \mathrm{~nm}$ The corresponding regression data, indicated reasonable linear relationship $\mathrm{R}^{2}=0.9887$ (not mentioned). Eight Commercial brands Metronidazole film coated tablets justifying in vitro dissolution behavior in two phases; one using buffer dissolution medium while the other contained equal volume of buffer dissolution medium with mango juice. The release rate of the samples was determined reputedly 5 minutes for around 60 minutes. M01 to M08 presented in the Table 1, Table 2, and Table 3 respectively.

Table 1. Percent Release of sample M01 to M08 gastric dissolution medium and in presence of mango juice

\begin{tabular}{|c|c|c|c|c|c|c|c|c|c|c|c|c|c|c|c|c|}
\hline \multicolumn{17}{|c|}{$\%$ of Release } \\
\hline $\begin{array}{c}\text { Time } \\
\text { (minutes) }\end{array}$ & $\begin{array}{c}\text { M01 } \\
\text { (x) }\end{array}$ & $\begin{array}{c}\text { M01 } \\
\text { (y) }\end{array}$ & $\begin{array}{c}\text { M02 } \\
\text { (x) }\end{array}$ & $\begin{array}{c}\text { M02 } \\
\text { (y) }\end{array}$ & $\begin{array}{c}\text { M03 } \\
\text { (x) }\end{array}$ & $\begin{array}{c}\text { M03 } \\
\text { (y) }\end{array}$ & $\begin{array}{c}\text { M04 } \\
\text { (x) }\end{array}$ & $\begin{array}{c}\text { M04 } \\
\text { (y) }\end{array}$ & $\begin{array}{c}\text { M05 } \\
\text { (x) }\end{array}$ & $\begin{array}{c}\text { M05 } \\
\text { (y) }\end{array}$ & $\begin{array}{c}\text { M06 } \\
\text { (x) }\end{array}$ & $\begin{array}{c}\text { M06 } \\
\text { (y) }\end{array}$ & $\begin{array}{c}\text { M07 } \\
\text { (x) }\end{array}$ & $\begin{array}{c}\text { M07 } \\
\text { (y) }\end{array}$ & $\begin{array}{c}\text { M08 } \\
\text { (x) } \\
\end{array}$ & $\begin{array}{c}\text { M08 } \\
\text { (y) }\end{array}$ \\
\hline 0 & 0 & 0 & 0 & 0 & 0 & 0 & 0 & 0 & 0 & 0 & 0 & 0 & 0 & 0 & 0 & 0 \\
\hline 5 & 36.31 & 38.9 & 58.75 & 60.32 & 48.17 & 51.98 & 42.98 & 48.86 & 49.12 & 51.52 & 50.28 & 53.28 & 62.67 & 64.23 & 43.21 & 45.81 \\
\hline 10 & 61.32 & 65.12 & 60.56 & 65.67 & 55.43 & 58.32 & 53.32 & 55.45 & 53.38 & 55.12 & 55.98 & 57.23 & 66.19 & 69.72 & 47.31 & 49.32 \\
\hline 15 & 65.83 & 67.31 & 70.19 & 72.43 & 59.56 & 60.43 & 58.21 & 60.34 & 59.98 & 62.45 & 58.43 & 60.28 & 72.98 & 76.34 & 50.22 & 54.21 \\
\hline 20 & 68.23 & 69.38 & 70.64 & 73.18 & 62.76 & 64.23 & 61.98 & 65.32 & 63.67 & 64.91 & 61.34 & 63.21 & 77.45 & 78.98 & 56.91 & 58.32 \\
\hline 25 & 71.89 & 72.65 & 70.96 & 77.49 & 65.67 & 67.98 & 64.31 & 66.89 & 70.43 & 74.13 & 63.22 & 65.24 & 80.12 & 82.12 & 60.57 & 62.45 \\
\hline 30 & 74.52 & 77.32 & 80.98 & 82.20 & 70.43 & 71.98 & 67.13 & 69.32 & 73.12 & 75.32 & 69.93 & 70.17 & 83.32 & 85.31 & 65.12 & 66.73 \\
\hline 35 & 80.23 & 82.81 & 83.78 & 85.98 & 72.81 & 74.32 & 70.20 & 72.71 & 76.32 & 77.18 & 73.54 & 75.32 & 87.12 & 88.91 & 69.13 & 70.98 \\
\hline 40 & 82.49 & 85.21 & 88.43 & 90.45 & 79.13 & 80.43 & 75.52 & 78.28 & 78.14 & 80.54 & 76.35 & 77.41 & 89.56 & 90.43 & 77.23 & 78.49 \\
\hline 45 & 88.21 & 89.69 & 93.19 & 94.69 & 82.81 & 84.76 & 79.34 & 80.32 & 82.67 & 85.13 & 80.21 & 82.89 & 91.76 & 93.51 & 79.12 & 82.56 \\
\hline 50 & 90.23 & 91.21 & 95.23 & 96.87 & 85.27 & 87.32 & 80.16 & 82.34 & 84.34 & 87.17 & 84.41 & 85.69 & 95.23 & 96.23 & 88.23 & 90.21 \\
\hline 55 & 91.78 & 94.51 & 98.21 & 98.87 & 90.45 & 92.32 & 82.89 & 84.92 & 88.12 & 90.61 & 90.65 & 92.34 & 97.13 & 98.12 & 92.32 & 94.10 \\
\hline 60 & 95.61 & 96.34 & 98.24 & 98.91 & 94.56 & 95.12 & 85.34 & 86.31 & 91.32 & 93.31 & 93.65 & 94.11 & 98.78 & 98.82 & 95.21 & 96.35 \\
\hline
\end{tabular}

$\mathrm{x}=$ Dissolution in gastric medium; $\mathrm{y}=$ Dissolution in gastric medium with mango juice 
Table 2. Percent remaining of sample M01 to M08 gastric dissolution medium and in presence of mango juice

\begin{tabular}{|c|c|c|c|c|c|c|c|c|c|c|c|c|c|c|c|c|}
\hline \multicolumn{17}{|c|}{ \% Remaining } \\
\hline $\begin{array}{c}\text { Time } \\
\text { (minutes) }\end{array}$ & $\begin{array}{c}\text { M01 } \\
\text { (x) }\end{array}$ & $\begin{array}{c}\text { M01 } \\
\text { (y }\end{array}$ & $\begin{array}{c}\text { M02 } \\
\text { (x) }\end{array}$ & $\begin{array}{c}\text { M02 } \\
\text { (y) }\end{array}$ & $\begin{array}{c}\text { M03 } \\
\text { (x) }\end{array}$ & $\begin{array}{c}\text { M03 } \\
\text { (y) }\end{array}$ & $\begin{array}{c}\text { M04 } \\
\text { (x) }\end{array}$ & $\begin{array}{c}\text { M04 } \\
\text { (y) }\end{array}$ & $\begin{array}{c}\text { M05 } \\
\text { (x) }\end{array}$ & $\begin{array}{c}\text { M05 } \\
\text { (y) }\end{array}$ & $\begin{array}{c}\text { M06 } \\
\text { (x) }\end{array}$ & $\begin{array}{c}\text { M06 } \\
\text { (y) }\end{array}$ & $\begin{array}{c}\text { M07 } \\
\text { (x) }\end{array}$ & $\begin{array}{c}\text { M07 } \\
\text { (y) }\end{array}$ & $\begin{array}{c}\text { M08 } \\
\text { (x) } \\
\end{array}$ & $\begin{array}{c}\text { M08 } \\
\text { (y) }\end{array}$ \\
\hline 0 & 100 & 100 & 100 & 100 & 100 & 100 & 100 & 100 & 100 & 100 & 100 & 100 & 100 & 100 & 100 & 100 \\
\hline 5 & 63.69 & 61.1 & 41.25 & 39.68 & 51.83 & 48.02 & 57.02 & 51.14 & 50.88 & 48.48 & 49.72 & 46.72 & 37.33 & 35.77 & 56.79 & 54.19 \\
\hline 10 & 38.68 & 34.88 & 39.44 & 34.33 & 44.57 & 41.68 & 46.68 & 44.55 & 46.62 & 44.88 & 44.02 & 42.77 & 33.81 & 30.28 & 52.69 & 50.68 \\
\hline 15 & 34.17 & 32.69 & 29.81 & 27.57 & 40.44 & 39.57 & 41.79 & 39.66 & 40.02 & 37.55 & 41.57 & 39.72 & 27.02 & 23.66 & 49.78 & 45.79 \\
\hline 20 & 31.77 & 30.62 & 29.36 & 26.82 & 37.24 & 35.77 & 38.02 & 34.68 & 36.33 & 35.09 & 38.66 & 36.79 & 22.55 & 21.02 & 43.09 & 41.68 \\
\hline 25 & 28.11 & 27.35 & 29.04 & 22.51 & 34.33 & 32.02 & 35.69 & 33.11 & 29.57 & 25.87 & 36.78 & 34.76 & 19.88 & 17.88 & 39.43 & 37.55 \\
\hline 30 & 25.48 & 22.68 & 19.02 & 17.8 & 29.57 & 28.02 & 32.87 & 30.68 & 26.88 & 24.68 & 30.07 & 29.83 & 16.68 & 14.69 & 34.88 & 33.27 \\
\hline 35 & 19.77 & 17.19 & 16.22 & 14.02 & 27.19 & 25.68 & 29.8 & 27.29 & 23.68 & 22.82 & 26.46 & 24.68 & 12.88 & 11.09 & 30.87 & 29.02 \\
\hline 40 & 17.51 & 14.79 & 11.57 & 9.55 & 20.87 & 19.57 & 24.48 & 21.72 & 21.86 & 19.46 & 23.65 & 22.59 & 10.44 & 9.57 & 22.77 & 21.51 \\
\hline 45 & 11.79 & 10.31 & 6.81 & 5.31 & 17.19 & 15.24 & 20.66 & 19.68 & 17.33 & 14.87 & 19.79 & 17.11 & 8.24 & 6.49 & 20.88 & 17.44 \\
\hline 50 & 9.77 & 8.79 & 4.77 & 3.13 & 14.73 & 12.68 & 19.84 & 17.66 & 15.66 & 12.83 & 15.59 & 14.31 & 4.77 & 3.77 & 11.77 & 9.79 \\
\hline 55 & 8.22 & 5.49 & 1.79 & 1.13 & 9.55 & 7.68 & 17.11 & 15.08 & 11.88 & 9.39 & 9.35 & 7.66 & 2.87 & 1.88 & 7.68 & 5.90 \\
\hline 60 & 4.39 & 3.66 & 1.76 & 1.09 & 5.44 & 4.88 & 14.66 & 13.69 & 8.68 & 6.69 & 6.35 & 5.89 & 1.22 & 1.18 & 4.79 & 3.65 \\
\hline
\end{tabular}

$\mathrm{x}=$ Dissolution in gastric medium; $\mathrm{y}=$ Dissolution in gastric medium with mango juice

Table 3. Percent log of remaining sample M01 to M08 gastric dissolution medium and in presence of mango juice

\begin{tabular}{|c|c|c|c|c|c|c|c|c|c|c|c|c|c|c|c|c|}
\hline \multicolumn{17}{|c|}{$\%$ log of Remaining } \\
\hline $\begin{array}{c}\text { Time } \\
\text { (minutes) }\end{array}$ & $\begin{array}{c}\text { M01 } \\
\text { (x) }\end{array}$ & $\begin{array}{c}\text { M01 } \\
\text { (y) }\end{array}$ & $\begin{array}{c}\text { M02 } \\
\text { (x) }\end{array}$ & $\begin{array}{c}\text { M02 } \\
\text { (y) }\end{array}$ & $\begin{array}{c}\text { M03 } \\
\text { (x) }\end{array}$ & $\begin{array}{c}\text { M03 } \\
\text { (y) }\end{array}$ & $\begin{array}{c}\text { M04 } \\
\text { (x) }\end{array}$ & $\begin{array}{c}\text { M04 } \\
\text { (y) }\end{array}$ & $\begin{array}{c}\text { M05 } \\
\text { (x) }\end{array}$ & $\begin{array}{c}\text { M05 } \\
\text { (y) }\end{array}$ & $\begin{array}{c}\text { M06 } \\
\text { (x) }\end{array}$ & $\begin{array}{c}\text { M06 } \\
\text { (y) }\end{array}$ & $\begin{array}{c}\text { M07 } \\
\text { (x) }\end{array}$ & $\begin{array}{c}\text { M07 } \\
\text { (y) }\end{array}$ & $\begin{array}{c}\text { M08 } \\
\text { (x) }\end{array}$ & $\begin{array}{c}\text { M08 } \\
\text { (y) }\end{array}$ \\
\hline 0 & 2 & 2 & 2 & 2 & 2 & 2 & 2 & 2 & 2 & 2 & 2 & 2 & 2 & 2 & 2 & 2 \\
\hline 5 & 1.80 & 1.79 & 1.62 & 1.60 & 1.71 & 1.68 & 1.76 & 1.71 & 1.71 & 1.69 & 1.70 & 1.67 & 1.57 & 1.55 & 1.75 & 1.73 \\
\hline 10 & 1.59 & 1.54 & 1.60 & 1.54 & 1.65 & 1.62 & 1.67 & 1.65 & 1.67 & 1.65 & 1.64 & 1.63 & 1.53 & 1.48 & 1.72 & 1.70 \\
\hline 15 & 1.53 & 1.51 & 1.47 & 1.44 & 1.61 & 1.60 & 1.62 & 1.60 & 1.60 & 1.57 & 1.62 & 1.60 & 1.43 & 1.37 & 1.70 & 1.66 \\
\hline 20 & 1.50 & 1.49 & 1.47 & 1.43 & 1.57 & 1.55 & 1.58 & 1.54 & 1.56 & 1.55 & 1.59 & 1.57 & 1.35 & 1.32 & 1.63 & 1.62 \\
\hline 25 & 1.45 & 1.44 & 1.46 & 1.35 & 1.54 & 1.51 & 1.55 & 1.52 & 1.47 & 1.41 & 1.57 & 1.54 & 1.30 & 1.25 & 1.60 & 1.57 \\
\hline 30 & 1.41 & 1.36 & 1.28 & 1.25 & 1.47 & 1.45 & 1.52 & 1.49 & 1.43 & 1.39 & 1.48 & 1.47 & 1.22 & 1.17 & 1.54 & 1.52 \\
\hline 35 & 1.30 & 1.24 & 1.21 & 1.15 & 1.43 & 1.41 & 1.47 & 1.44 & 1.37 & 1.36 & 1.42 & 1.39 & 1.11 & 1.04 & 1.49 & 1.46 \\
\hline 40 & 1.24 & 1.17 & 1.06 & 0.98 & 1.32 & 1.29 & 1.39 & 1.34 & 1.34 & 1.29 & 1.37 & 1.35 & 1.02 & 0.98 & 1.36 & 1.33 \\
\hline 45 & 1.07 & 1.01 & 0.83 & 0.73 & 1.24 & 1.18 & 1.32 & 1.29 & 1.24 & 1.17 & 1.30 & 1.23 & 0.92 & 0.81 & 1.32 & 1.24 \\
\hline 50 & 0.99 & 0.94 & 0.68 & 0.50 & 1.17 & 1.10 & 1.30 & 1.25 & 1.19 & 1.11 & 1.19 & 1.16 & 0.68 & 0.58 & 1.07 & 0.99 \\
\hline 55 & 0.91 & 0.74 & 0.25 & 0.05 & 0.98 & 0.89 & 1.23 & 1.18 & 1.07 & 0.97 & 0.97 & 0.88 & 0.46 & 0.27 & 0.89 & 0.77 \\
\hline 60 & 0.64 & 0.56 & 0.25 & 0.04 & 0.74 & 0.69 & 1.17 & 1.14 & 0.94 & 0.83 & 0.80 & 0.77 & 0.09 & 0.07 & 0.68 & 0.56 \\
\hline
\end{tabular}

$\mathrm{x}=$ Dissolution in gastric medium; $\mathrm{y}=$ Dissolution in gastric medium with mango juice

To understand the release kinetics other tablet matrix According to percent release vs. time (Figure 2), the log of with Mango juice dissolution corresponding data were canvassed by various dissolution kinetics models such as Zero Order, First Order, Higuchi, and Hixon-Crowell etc. release percent release vs. time (Figure 3), percent release vs. square root time (Figure 4) and cube root percent of release vs. time respectively (Figure 5) [22,23].

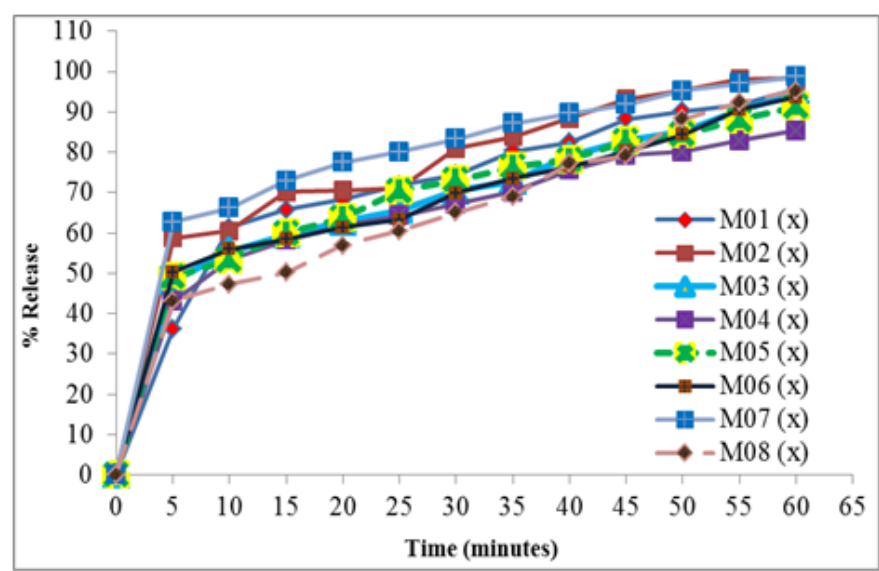

(a)

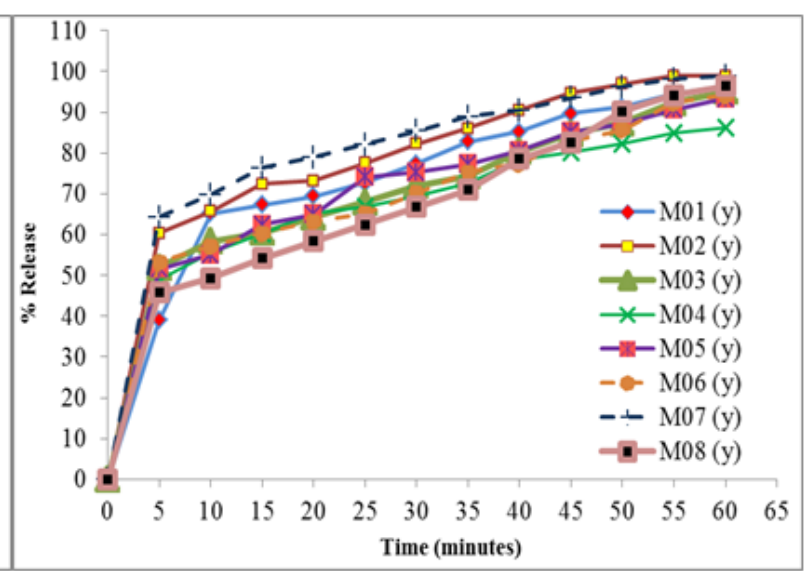

(b)

Figure 2. Zero Order plots to ascertain release kinetics of different Metronidazole samples (a) and metronidazole samples with including mango juice (b) 


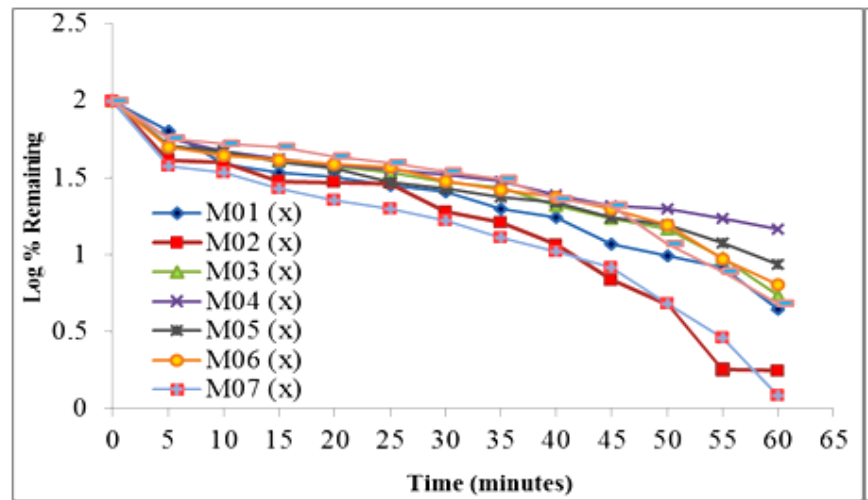

(a)

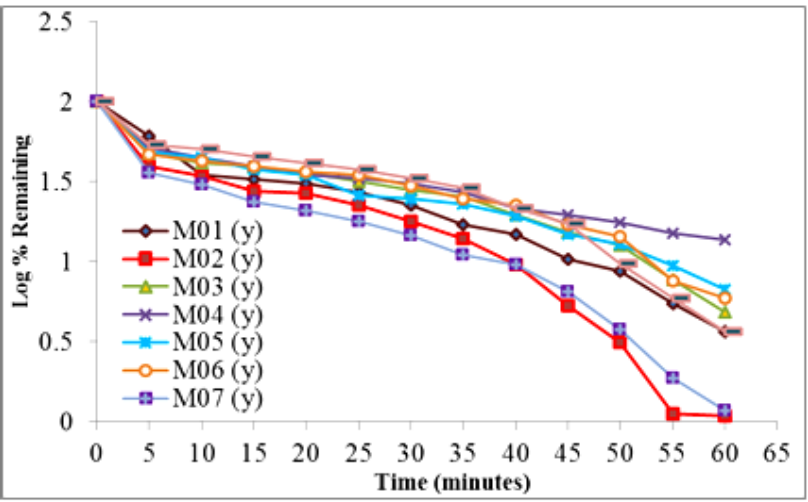

(b)

Figure 3. First Order plots to ascertain release kinetics of different Metronidazole samples (a) and metronidazole samples with including mango juice (b)

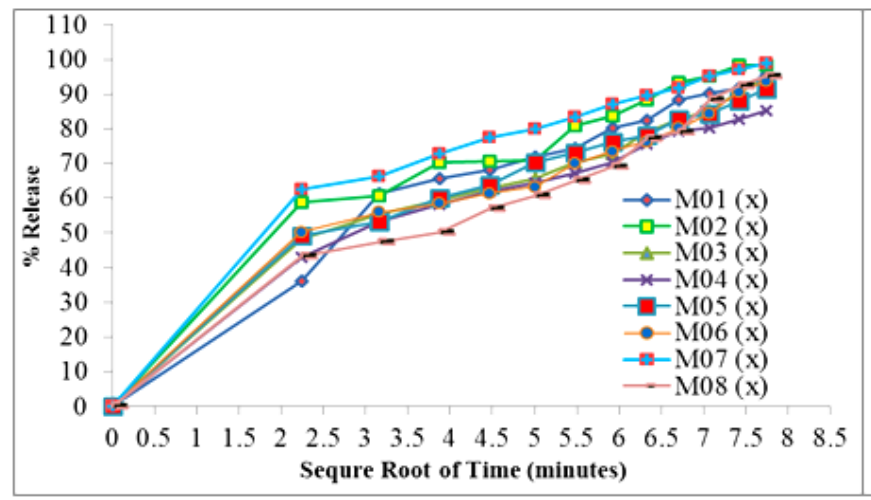

(a)

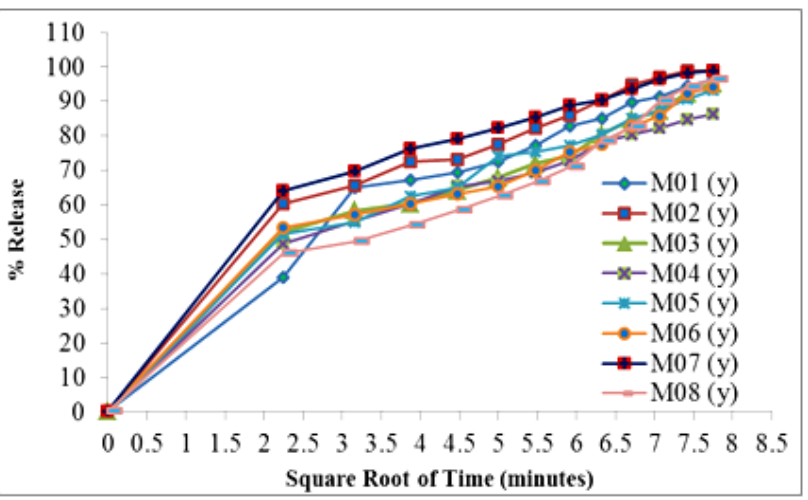

(b)

Figure 4. Higuchi plots to ascertain release kinetics of different Metronidazole samples (a) and metronidazole samples with including mango juice (b)

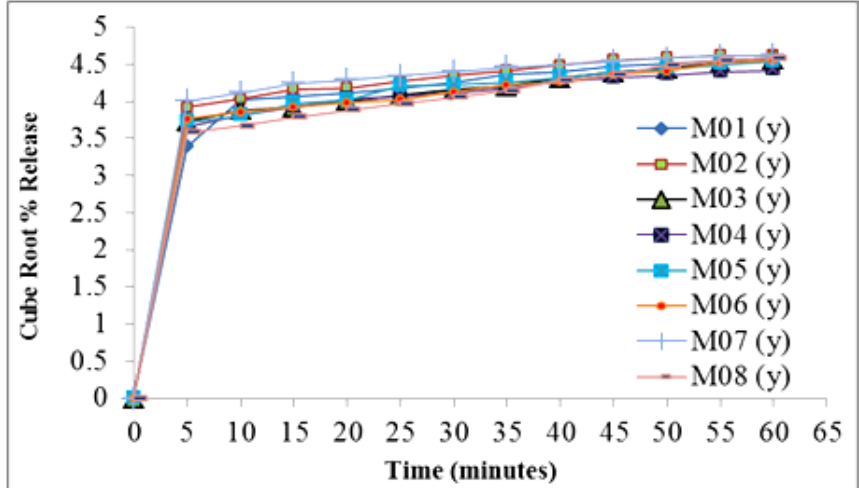

(a)

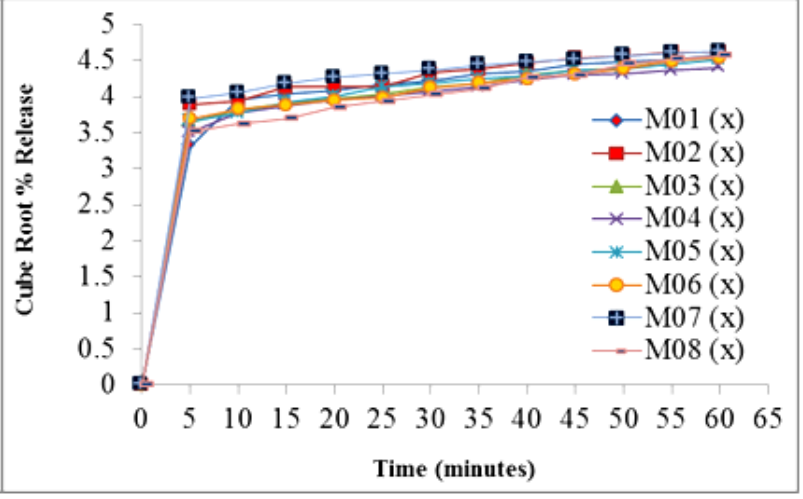

(b)

Figure 5. Hixon-Crowell plots to ascertain release kinetics of different Metronidazole samples (a) and metronidazole samples with including mango juice (b)

In this study film coated tablet was used as a sample, so the initial drug release percentage in 5 minuets all the drug releases on average $48.93 \%$ and $51.86 \%$ in presence of mango juice. The drug rate of release controlled by increase or decrease in the drug solubility and concentration of drug in matrix system. Also dissolution depends on the surrounding medium. In dissolution medium kinetics Higuchi model found more eminently fitted which represent percent release vs. square root time (Figure 4). Also the comparison of the multiple correlation coefficient constituted in Table 4 and Table 5.

In gastric dissolution medium,Zero Order, First Order, higuchi and Hixon-Crowell correlation coefficient were demonstrated in Table 4. Here, Higuchi correllation coefficient predominant the dissolution release kinetics.
Table 4. Representation of correlation coefficient $\left(R^{2}\right)$ of remaining sample M01 to M08 gastric dissolution medium

\begin{tabular}{|c|c|c|c|c|}
\hline Sample & Zero Order & First Order & Higuchi & Hixon-Crowell \\
\hline M01 (x) & 0.76 & 0.96 & 0.94 & 0.43 \\
\hline M02 (x) & 0.72 & 0.92 & 0.91 & 0.38 \\
\hline M03 (x) & 0.78 & 0.925 & 0.93 & 0.41 \\
\hline M04 (x) & 0.74 & 0.95 & 0.93 & 0.39 \\
\hline M05 (x) & 0.75 & 0.96 & 0.94 & 0.41 \\
\hline M06 (x) & 0.77 & 0.91 & 0.92 & 0.41 \\
\hline M07 (x) & 0.97 & 0.92 & 0.86 & 0.35 \\
\hline M08 (x) & 0.97 & 0.91 & 0.97 & 0.48 \\
\hline
\end{tabular}


Table 5. Representation of correlation coefficient $\left(R^{2}\right)$ of remaining sample M01 to M08 gastric dissolution medium

\begin{tabular}{|c|c|c|c|c|}
\hline Sample & Zero Order & First Order & Higuchi & Hixon -Crowell \\
\hline M01 (y) & 0.74 & 0.96 & 0.93 & 0.43 \\
\hline M02 (y) & 0.68 & 0.92 & 0.89 & 0.38 \\
\hline M03 (y) & 0.75 & 0.93 & 0.92 & 0.41 \\
\hline M04 (y) & 0.71 & 0.94 & 0.91 & 0.39 \\
\hline M05 (y) & 0.74 & 0.96 & 0.92 & 0.41 \\
\hline M06 (y) & 0.75 & 0.91 & 0.91 & 0.35 \\
\hline M07 (y) & 0.97 & 0.94 & 0.84 & 0.48 \\
\hline M08 (y) & 0.97 & 0.9 & 0.96 & 0.41 \\
\hline
\end{tabular}

In gastric dissolution medium with mango juice,Zero Order, First Order, Higuchi and Hixon-Crowell correlation coefficient were demonstrated in Table 5. Here, Higuchi correllation coefficient predominant the dissolution release kinetics.

In vitro dissolution study subsequently completed in two different phases, the release rate of 04 brands found relatively faster in total 08 brands on medium containing mango juice and after 15 to 50 minutes the Metronidazole release was increasing in presence of mango juice was observed. The average results of Metronidazole releasing rate of 15 to 50 minutes were M02 (81.68\%), M05 (73.58\%), M06 (70.92\%) and M07 (84.69\%) in the gastric dissolution medium. Also in mango juice medium samples were M02 (84.79\%), M05 (75.86\%), M06 (72.53\%) and M07 (86.48\%). Which might be a denotation of reaction between the drug and the components of mango juice. All the brands were fulfill according to BP in vitro dissolution specification within 45 minutes in acidic media, pharmacopeia specifies that the metronidazole tablets should have a potency of between $95.0 \%$ to $105.0 \%$. All brands were fulfill the specification in presence of mango juice. After 1 hour, All brands released more than 90\% of drug in presence of mango juice. It was observed that mango juice partially initiates the release of metronidazole release in vitro dissolution medium.

\section{Conclusion}

In this study, revealed that most of the commercial brands of Metronidazole film coated tablets in Bangladesh met the official specification even further presence of mangojuice. There is no specific drug interaction study formed most of the drugs in Bangladesh. We are attempting to conduct an in vitro study dissolution of drugs with mango juice only. Further broadly research is must necessitate.

\section{Acknowledgments}

We are grateful to the Pharmaceutical Technology Lab, State University of Bangladesh for providing facilities and technical support.

\section{References}

[1] Tally, F.P., Sullivan, C.E., Metronidazole: in vitro activity, pharmacology and efficacy in anaerobic bacterial infections, Pharmacotherapy, 1(1):28-38, 1981.

[2] Nigwekar, S.U., Casey, K.J., Metronidazole Induced Pancreatitis. A Case Report and Review of Literature, JOP. J Pancreas (Online) 5(6): 516-519, 2004.

[3] Alhalabi, Z., Al-khayat, M.A., Haidar, S. Separation And Assay Of Antiprotozoal Imidazole Derivatives (Metronidazole, Tinidazole And Secnidazole) By Rp-Hplc, International Journal of Pharmaceutical Sciences Review and Research, 13(1), 12-18, 2012.

[4] Budhiraja R.D.,Elementary Pharmacology \& Toxicology, Popular prakashan, Mumbai, 2009, 432-433.

[5] Dahan, A. and Altman, H., Food-drug interaction: grapefruit juice augments drug bioavailability Fmechanism, extent and relevance. European Journal of Clinical Nutrition, 58, 1-9, 2004.

[6] Sugimoto K., Araki, N., Ohmori, M., Harada, K., Cui, Y., Tsuruoka S., Kawaguchi A., Fujimura A. Interaction between grapefruit juice and hypnotic drugs: comparison of triazolam and quazepam. Eur. J. Clin. Pharmacol. 62(3): 209-15. 2006.

[7] Bailey, DG and Dresser, GK. Interactions between grapefruit juice and cardiovascular drugs. Am J Cardiovasc Drugs, 4(5): 281-97. 2004.

[8] Lee, A.J., Chan, W.K., Harralson, A.F., Buffum, J., Bui, BC.The effects of grapefruit juice on sertraline metabolism: an in vitro and in vivo study. Clin Ther. 21(11): 1890-9.1999.

[9] Bailey, D.G and Dresser, G.K. Grapefruit juice increases serum concentrations of atorvastatin and has no effect on pravastatin. $\mathrm{Br}$ J Clin Pharmacol, 57(4):448-55. 2004.

[10] Gasche, Y., Daali, Y., Fathi, M., Chiappe, A., Cottini, S., Dayer, P., Desmeules, J. Codeine intoxication associated with ultrarapid CYP2D6 metabolism. N. Engl. J. Med. 351(27): 2827-31. 2004.

[11] Benmebarek, M., Devaud, C., Gex-Fabry, M., Golay, PK., Brogli, C., Baumann P., Gravier B., Eap, C.B. Effects of grapefruit juice on the pharmacokinetics of the enantiomers of methadone. Clinical Pharmacology \& Therapeutics, 76(1): 55. 2004.

[12] Paine, M.F., Widmer, W.W., Pusek, S.N., Beavers, K.L., Criss, A.B., Snyder, J., Watkins P.B. Further characterization of a furanocoumarin-free grapefruit juice on drug disposition: studies with cyclosporine. American Journal of Clinical Nutrition, 87(4), 863-871. 2008.

[13] Hori, H., Yoshimura, R., Ueda, S., Fluvoxamine, in vivo study. $J$ Clin Psychopharmacol. 23(4): 422-424.2004.

[14] Jetter, A., Kinzig-Schippers, M., Walchner-Bonjean, M., Hering, U., Bulitta, J., Schreiner, P., Sörgel, F., Fuhr, U., Effects of grapefruit juice on the pharmacokinetics of sildenafil. Clin. Pharmacol. Ther. 71(1): 21-9.2002.

[15] Arayne, M.S., Sultana, N., Bibi, Z., Grape fruit juice-drug interactions. Pak J Pharm Sci, 18(4):45-57.2005.

[16] Augsburger, L.L., Shangraw, R.F., Giannini, R.P., Shah, V.P., Prasad, V.K. and Brown, D. Thiazides VIII: Dissolution Survey of marketed Hydrochlorothiazide tablets. J. Pharm. Sci., 72(8): 876881. 1983.

[17] Ayres, JW., Huang, H. and Albert, K., Effect of polymer in sustained release matrix tablet. J. Pharm. Sci, 73: 1629. 1984.

[18] Sungthongjeen, S., Pitaksuteepong, T., Somsiri, A. and Sriamornsak, P. Studies on pectin's as potential hydrogel matrices for controlled-release drug delivery. Drug. Dev. Ind. Pharm., 25(12): 1271-1276. 1999.

[19] Yaheya, M., Ismail, M. Review Article Drug-Food Interactions And Role Of Pharmacist, Asian Journal Of Pharmaceutical And Clinical Research, 2(4):1-10. 2009.

[20] British Pharmacopoeia, 2012, Vol. V: 57-58.

[21] Halder,S., Shuma, M.L., Kabir,A.K.L., Rouf, A.S.S,In vitro release kinetics study of Esomeprazole Magnesium Trihydrate tablet available in Bangladesh and comparison with the originator brand (Nexium $\left.{ }^{\circledR}\right)$, S. J. Pharm. Sci. 4(1): 79-83.2011.

[22] United States Pharmacopeia 30 and National Formulary 25. The United States Pharmacopeial Convention, CD ROM, 2007.

[23] Hixon, A.W., Crowell, J.H., Ind Eng Chem, 23, 923-931.1931.

[24] Musa, H, Sule,Y.Z, and Gwarzo,M.s., Assessment of Physicochemical Properties Of Metronidazole Tablets Marketed In Zaria, Nigeria, International Journal of Pharmacy and Pharmaceutical Sciences, Int J Pharm Pharm Sci, 3(3): 27-29. 2010. 